\title{
Cartography of the evolution of the shoreline of Baguida- Agbodrafo (South-East Togo) from 1986 to 2017: contribution of the tool "Mobilitéde Trait de Côte (MobiTC)"
}

KASSI Ahon Jean-Baptiste ${ }^{\# 1}$,AFFO DJOBO Atcha ${ }^{\# 2}$,KOUADIO Maffoue Jeanne ${ }^{\# 3}$ \#1 Centre Universitaire de Recherche et d'Application en Télédétection (CURAT)/UFHB, +22507362070/ 046969 45. Email : ahonjb.kassi@ curat-edu.org

\#2 Centre Universitaire de Recherche et d'Application en Télédétection (CURAT)/UFHB, +228919931 23. Email :affodjoboatcha@gmail.com

\#3 Centre Universitaire de Recherche et d'Application en Télédétection (CURAT)/UFHB, +22507 7352 60. Email : kouadiomaffoue2006@yahoo.fr

\section{ABSTRACT}

Like the coasts of the world, the phenomenon of coastal erosion is manifested on the entire coast of Togo and has continued to be acute since the construction of the Autonomous Port of Lome in 1967. It is characterized by the destruction of socio-economic goods (infrastructures, habitats and tourist sites). On the coasts of the Baguida and Agbodreafo cantons in particular, erosion threatens fishing activities, the beach economy, tourist sites and villages such as Gbodjomé, Gbétsogbé, Agbavi, DoèviKopé and Payimé. In order to contribute to sustainable coastal development choices in Baguida-Agbodrafo, this study aims to characterize the dynamics of the coastline by producing a map of coastal erosion at the local scale for better appreciation of the phenomenon of erosion. To do this, the geomatics approach consisted of extracting and compiling the various shoreline from the 1986, 2001, 2010, 2013, and 2017 Landsat images of the study area. The measurement of shoreline development in this area of the coastline was done through the MobiTC Software. The variations observed between 1986 and 2017 show an eroding coastline at an average rate of $2.92 \mathrm{~m} /$ year.

Key words: coastal erosion; mapping; MobiTC; geomatics; Baguida-Agbodrafo; Togo.

\section{Corresponding Author:KASSI Ahon Jean-Baptiste}

\section{INTRODUCTION}

The coastline is an environment that is home to about $70 \%$ of the world's population [1] and whose cities concentrate significant economic activities and more than $30 \%$ to $45 \%$ of the population[2] is in danger [3] due to coastal erosion.

Globally, over $70 \%$ of their length, sandy or gravelly coasts are in decline, while only $20 \%$ are stable and only $10 \%$ in advanced [4]. Of the $9788 \mathrm{~km}$ estimated from Mauritania to Benin, 67\% 
are of unstable and / or highly dynamic coasts, 30\% less dynamic coasts and only 3\% rocky coastlines [5]. Thus almost all of the West African coast has a high sensitivity to erosion [6].

On the coast of Togo, the problem of erosion follows the construction of the port of Lome in 1967 and continues to arise acutely, causing human and economic losses [7] (Blivi and Adjoussi, 2004). The erosion of the coast has caused Togo to lose two international routes in 40 years.

In the perspective of an efficient integrated management of the coastal zone, methodologies and techniques including surveying, photo-interpretation and the use of imagery for which aerial and satelite photography has long been used in studies of the dynamics of the shoreline. In the recent past automated tools (DSAS, MobiTC) for coastline processing have been developed.It would be interesting to experiment with these tools for better decision-making in the management of the Togolese coast. It is with this in mind that this study entitled use of the Mobilté de Trait de Côte (MobiTC) for mapping the evolution of the shoreline of the BaguidaAgbodrafo coastline in South-East Togo from 1986 to 2017 is initiated to provide an appropriate coastal development that fits into the challenge of sustainable development.

\section{1- PRESENTATION OF THE STUDY AREA}

The Togolese coast is limited by latitudes $6^{\circ} \mathrm{N}$ to the North and $6^{\circ} 30^{\prime} \mathrm{N}$ to the South, and parallels $1^{\circ} \mathrm{E}$ to the East and $1^{\circ} 50^{\prime} \mathrm{E}$ to the West. It lies between the maritime boundary of the Exclusive Economic Zone (EEZ) and the continental located $50 \mathrm{~km}$ beyond the zone of influence of the average tide [8].

The coastal area of Baguida-Agbodrafo is located between the longitude $6^{\circ} 8^{\prime} 0^{\prime \prime}$ and $6^{\circ} 15^{\prime} 0^{\prime \prime}$ North and the latitude $1^{\circ} 32^{\prime} 0$ " and $1^{\circ} 18^{\prime} 0$ East of the Togolese coast.

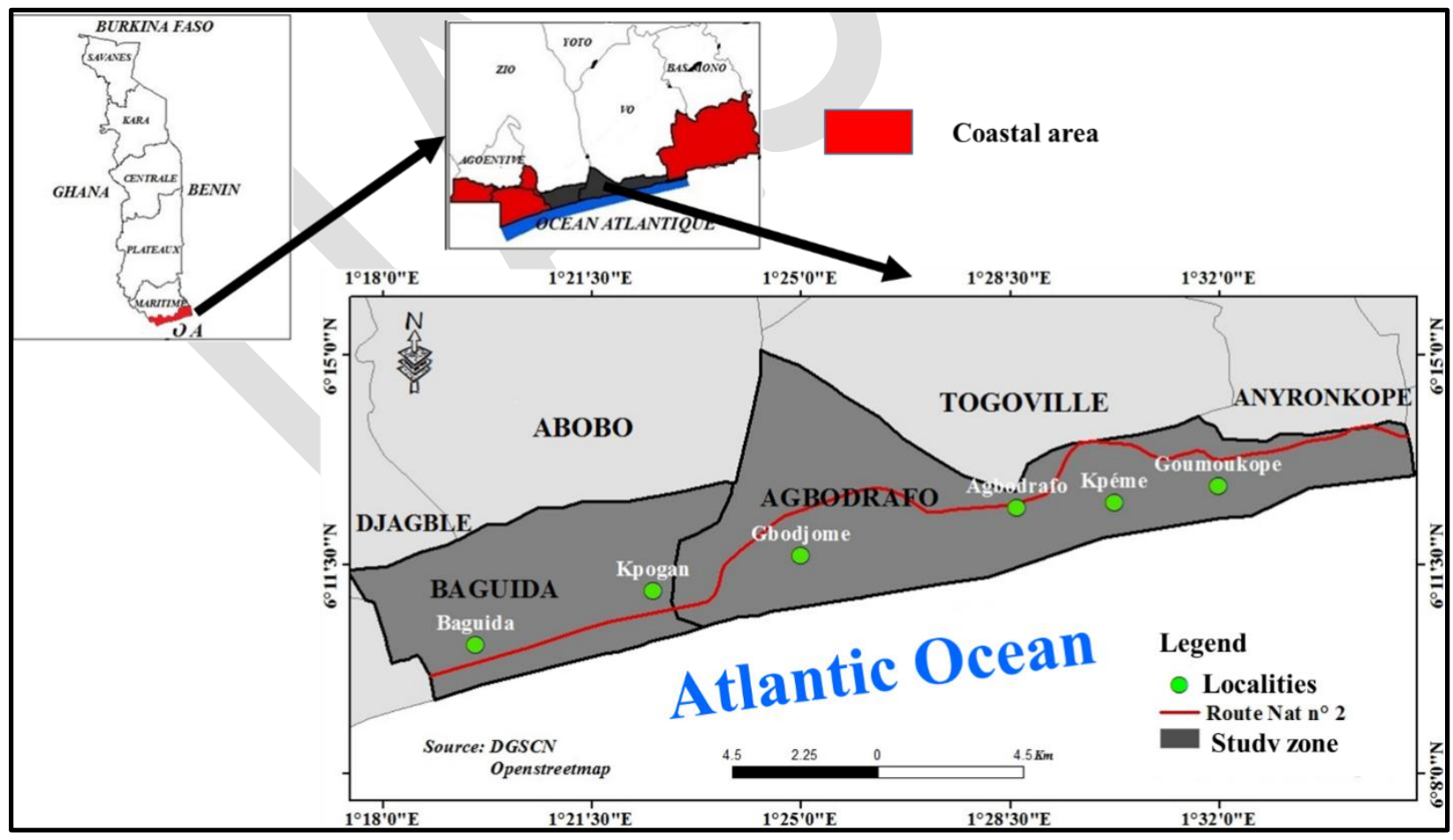

Figure 1: Location map of the study area 


\section{2- DATA}

Five Landsat images of the 192/56 scene were used for the local analysis of the coastline dynamics of the Baguida and Agbodrafo cantons. It consists of one (1) TM image, two (2) ETM+ images and two (2) OLI orthorectified and georeferenced images.

\section{3- METHODS}

It includes the extraction of coastlines and the estimation of coastal dynamics.

\section{3-1- Extractions of shorelines}

Beforehand, we must determine the instantaneous line of shoreline, which is the only line of reference visible on the images. It was carried out on channels 5 and 2 of TM and ETM+ sensors and on channels 6 and 3 of the OLI sensor. The study area is extracted according to the administrative boundaries using the ENVI software Subset Data from ROIs algorithm.

To extract the shoreline; Band-Ratio Band Ratio algorithm on ENVI, the famous B5 / B2 ratio of Landsat TM and ETM + images, and the corresponding B6 / B3 for OLI are produced. Then an unsupervised K-means classification of the Unsupervised Classification module on ENVI is applied and selected two classes according to the results of the band ratios. A vectorization (Classification to Vector of the Post Classification of the module Classification on ENVI) and a conversion into shapefile (Classic EVF to Shapefile of the Vector module on ENVI) classified images are made and finally the coastline at different dates are obtained under digitalization under ArcGis

An estimate of the areas gained or lost is made by superimposing and intersecting the coastlines of the different dates at the same level. They are merged to form a single theme with ArcToolsbox and then converted into polygons in ArcCatalog, which automatically calculates surfaces.

\section{3-2- Estimation of littoral dynamics}

The determination of the evolution of coastline dynamics on MobiTC follows four (4) fundamental steps (Figure 3):

- the preparation and formatting of coastlines;

- the realization of a baseline;

- the realization of traces and;

- the calculation of the evolution of the coastline traces by trace

- Preparation and formatting of coastlines

It consists in configuring the coastlines so that it can be used on the MobiTC software. Coastlines must have the same projection, be in mif / mid format and be named as followsANNEE1-MOIS1-JOUR1-ANNEE2-MOIS2-JOUR2-TDC-Fxxxxxxxx-PRJfxxx-LIMxxLEV/NUM-ERRxxnom_projet. There was talk of defining the coastline names based on their $\mathrm{mg} /$ mid metadata under Qgis for baseline creation

- Realization of the baseline

The baseline is the "point 0 ", from which the distance to the different shorelines will be calculated and transformed into shoreline evolution. In MobiTC, this baseline is realized automatically from the set of different shorelines available, representing the median. The principle of skeletonization has been retained. It consisted of: 
- create an envelope containing the coastlines by performing a triangularization based on points of the various TDCs;

- perform a skeletonization which is the generation of a median line through the envelope, in MobiTC from the Voronoi diagram and points located on the nodes of the envelope contour, and located all the zzz $\mathrm{m}$ (distance of cut of the envelope).

- Realization of traces

The traces are perpendicular to the baseline. We first orient the different segments of the baseline to characterize the best fattening or erosion. The traces are then created by defining a distance of $5 \mathrm{~m}$ between the tracks which are each $500 \mathrm{~m}$ long and give an orientation towards the ground of the baseline.

- Calculation of the evolution of the coastline transect by transect

For the calculation of the evolution of the trace coastline one calculates first the distances between the coastline and the baseline along each track. Two files are created, the first contains all the points of intersection and the second only takes the chosen points. This last file is used for the computation of the evolution trace by trace which gave the files mif / mid in the form of histograms representing the variation of the spatial tendency of the evolution of the line which will be visualized.

\section{4- RESULTS}

\section{4-1- Result of shoreline evolution}

The graphical analysis (Figure 4) of the position of the instantaneous shoreline between 1986 and 2017 on the Baguida-Agbodrafo sector shows an erosive evolution of 2,680,106 $\mathrm{m}^{2}$ over the period, ie a loss of $86,455.03 \mathrm{~m}^{2}$ / year of the coastline in this place. However it should be noted a fattening of 28,309 $\mathrm{m}^{2}$ (a gain 913,20 $\mathrm{m}^{2}$ / year) over the period between Kpémé and Goumoukope.

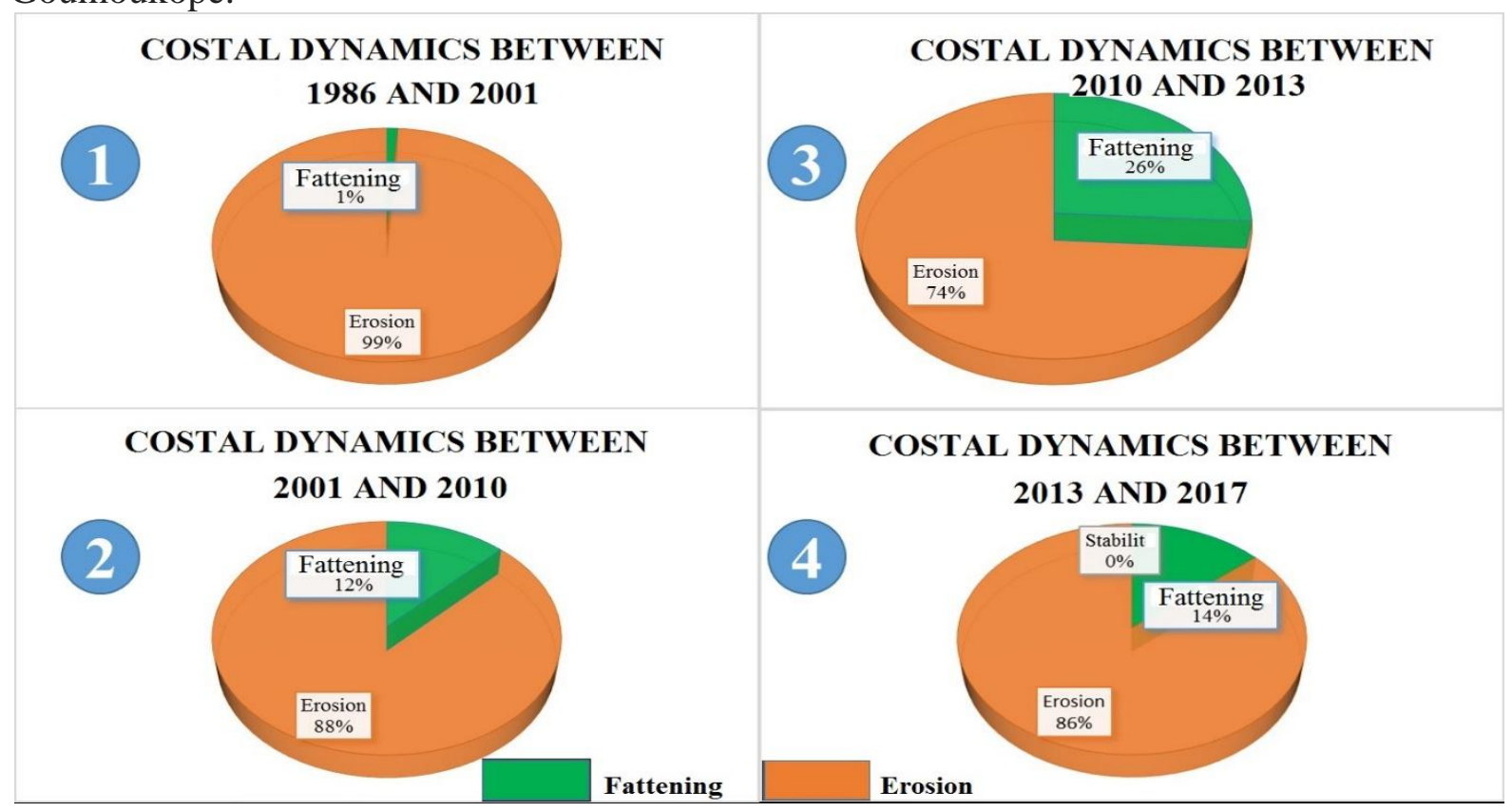

Figure 4: Schemes of Coastal Dynamics from 1986 to 2017 


\section{4-2- Statistical and graphical measurement of shoreline evolution with MobiTC}

The production of the 6288 (Table I) transects to determine the erosion rate (OLS) on the coasts of Baguida and Agbodrafo enabled us to draw up a negative assessment of shoreline evolution, ie an annual average of $-2,71 \mathrm{~m} /$ year with a loss of $84.01 \mathrm{~m}$ over the study period. Indeed, $96 \%$ of this fringe of the coast is eroding and $4 \%$ in fattening with an erosion rate of $-2.92 \mathrm{~m} /$ year (a loss of $90.52 \mathrm{~m}$ ) for $0.71 \mathrm{~m} /$ year (a gain of $22.01 \mathrm{~m}$ ) of fattening rate.

Table I: Statistics generated by MobiTC of the Baguida-Agbodrafo study area

\begin{tabular}{|c|c|c|c|c|c|}
\hline Transect Id & baseline & Dates of shoreline & Distance & EPR(m/an) & OLS(m/an) \\
\hline \multirow[t]{5}{*}{6288} & \multirow[t]{5}{*}{1} & $13 / 01 / 1986$ & \multirow[t]{5}{*}{30000} & \multirow[t]{5}{*}{$-2,78$} & \multirow[t]{5}{*}{$-2,71$} \\
\hline & & $04 / 04 / 2001$ & & & \\
\hline & & 23/01/2010 & & & \\
\hline & & $25 / 01 / 2013$ & & & \\
\hline & & $18 / 01 / 2017$ & & & \\
\hline
\end{tabular}

The erosion rate (EPR) balance is also negative and averages $-2.78 \mathrm{~m} /$ year. The fattening speed is $0.81 \mathrm{~m} /$ year on average and that of erosion is $-2.92 \mathrm{~m} /$ year. These values confirm the erosive trend of the study area.

\section{4-3- Graphical and statistical analysis by sector based on OLS}

Table II below summarizes the rate of erosion in the different sectors: Baguida-Kpogan, KpoganAgbodrafo and Agbodrafo-Goumoukope. Erosion rates are overall negative. The KpoganAgbodrafo sector has the highest erosion rates averaging -4.32, a loss of about $132.78 \mathrm{~m}$ over the study period. The trend towards negative kinematics of coastlines is confirmed once more (Figure 5). However, this trend is average in the Baguida-Kpogan sector (-2.63 m / year, a loss of $81.40 \mathrm{~m})$ and low in the Agbodrafo-Goumoukope sector $(-1.43 \mathrm{~m} /$ year, a loss of $44 \%) .41 \mathrm{~m}$ over the study period)

Table II: Statistics generated by MobiTC by sector

\begin{tabular}{|c|c|c|c|c|}
\hline Transects & Sectors & Baseline & Shoreline date & OLS (m/an) \\
\hline 1415 & Baguida-Kpogan & 1 & $13 / 01 / 1986$ & $-2,63$ \\
\cline { 4 - 4 } & & & $04 / 04 / 2001$ & \\
\hline 2334 & Kpogan- Agbodrafo & 1 & $23 / 01 / 2010$ & $-4,32$ \\
\cline { 4 - 4 } & & & $25 / 01 / 2013$ & \\
\hline 2539 & Agbodrafo-Goumoukope & 1 & $18 / 01 / 2017$ & $-1,43$ \\
& & & & \\
\hline
\end{tabular}




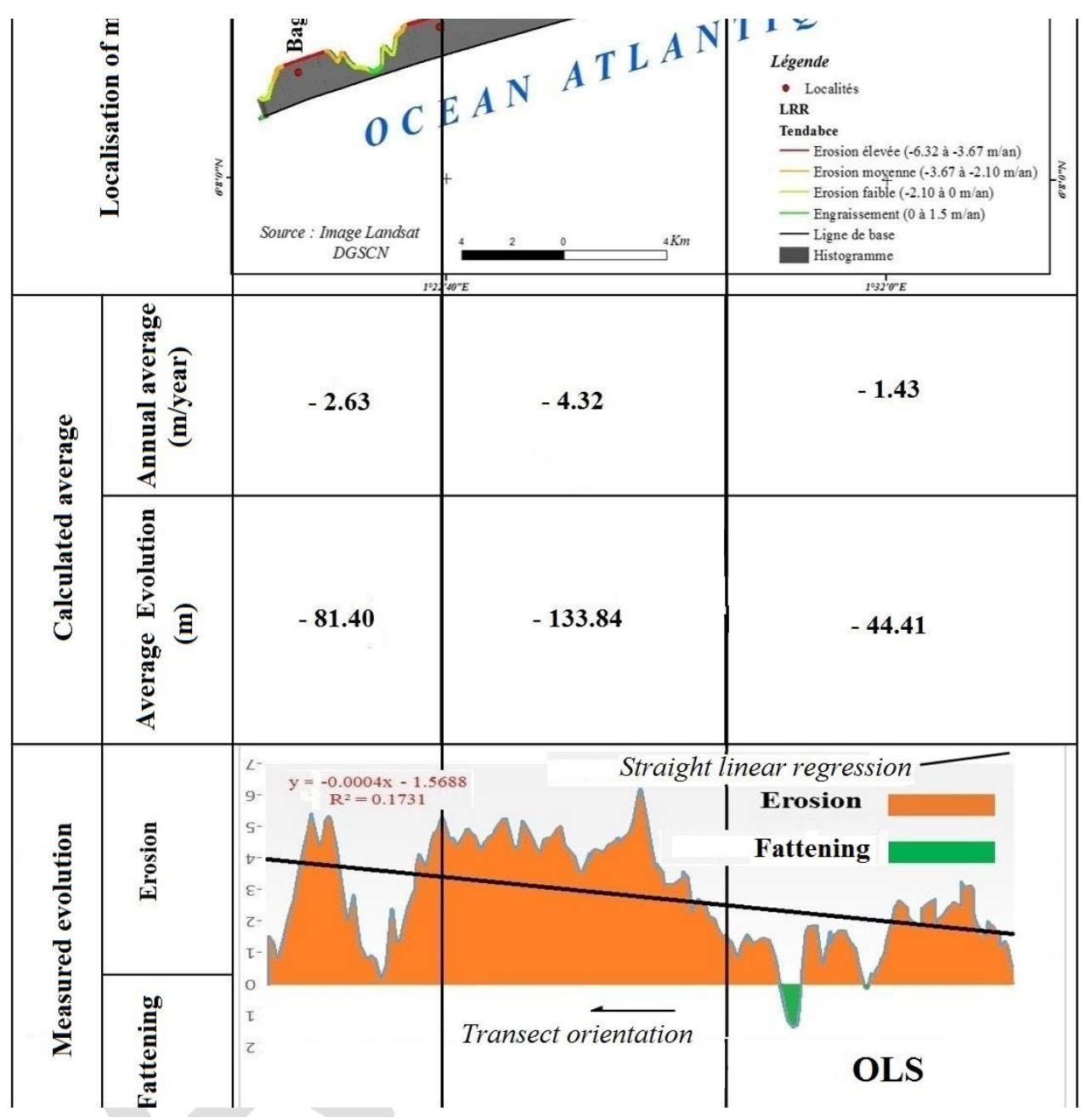

Figure 6: Evolution of the erosion and fattening rate of the Baguida-Agbodrafo coastline sectors by the linear regression method (OLS)

\section{5- DISCUSSION}

This study on the cartography of the dynamics of the coastline is based mainly on LANDSAT satellite data and the geomatic approach with the compilation of data from these images in the MobiTC software.

Indeed, several methodologies are used in the determination of the kinematic of the coastline and none of it is unanimous because what counts is the result. Authors like [9]; [10]; [11]; [12]rely on newer and more efficient techniques for mapping the evolution of the coastline.They used satellite images, extracted the different shorelines and integrated them in the DSAS tool designed for mapping the evolution of shorelines.

For this study, the same methodology was used with the only difference that the MobiTC software was exploited. Through its use, the mapping of the evolution of the shoreline of the study area was carried out. This cartography expresses a regressive evolution. 
This result comforts because it reflects the reality on the ground and is consistent with the conclusions of the studies already carried out on the Togolese coast. In comparison with the results of the studies carried out on the same study area, the true study of the coastal dynamics in a geomatic approach that was analyzed is that carried out by Blivi and Adjoussi in 2004. The others are studies and reports of order general about the Togolese coastal zone and all speak of a shoreline retreat of the central segment of about $25 \mathrm{~km}$.

The results of this study confirm previous studies and report findings. However for the period 1986-2001Blivi and Adjoussiin 2004 estimated the decline between 6-8 m / year while the results from 1986 to 2017 are about $3 \mathrm{~m} /$ year of decline. These divergences can be explained by the diversity of reference lines, data sources and methodological approaches used.

\section{CONCLUSION}

The shoreline of Baguida and Agbodrafo cantons is an area where erosion continues. This is confirmed in this study through the use of the MobiTC software designed for mapping the evolution of the coastline. The study area is in a regressive evolution of about $3 \mathrm{~m} /$ year over the study period. At the finish three large sets of erosion zones emerge.

The first set is characterized by a high erosion on which special attention must be paid. It is all covered by Kpogan, Gbodjome and Agbodrafo villages with an erosion rate of about $5 \mathrm{~m}$. The second set is that covered by the villages Baguida and Kpogan characterized by an average erosion rate of about $3 \mathrm{~m}$. The third set is the one crossed by the villages Agbodrafo, Kpémé and Goumoukope with a low erosion rate of about $1.5 \mathrm{~m}$. This area is a fattening area better a zone of stability benefiting from the installation of the ears.

\section{REFERENCES}

[1] HZAMI A., OULA A., THOURAYA B., KAMEL R., (2016). Suivi par SIG et télédétection de l'évolution spatio-temporelle de la frange littorale Nabeul-Hergla (Golfe de Hammamet, Tunisie).

[2] ADJOUSSI P., (2008). Vulnérabilité des systèmes côtiers a l'élévation du niveau marin entre la volta et le mono dans le Golfe du Benin (Afrique de l'Ouest). UL.

[3] PASKOFF R., (1998). La crise des plages : pénurie de sédiments. Mappemonde 52, 11-15.

[4] BIRD E.C.F., (1985). Coastline changes. A global review. John Wiley \& Sons, Chichester, New York, Brisbane, Toronto, Singapore.

[5] UEMOA, (2010). Etude de suivi de trait de côte et schéma directeur littoral de l'Afrique de l'Ouest : Schéma directeur, prescription générale.

[6] DEGBE C. G. E., (2009). Géomorphologie et érosion côtière dans le Golfe de Guinée. Université d'Abomey-Calavi, Cotonou. 
DOI : https://dx.doi.org/10.26808/rs.st.i8v1.10

International Journal of Advanced Scientific and Technical Research $\quad$ Issue8 volume 1 January-February 2018 Available online on http://www.rspublication.com/ijst/index.html

ISSN 2249-9954

[7] BLIVI A.B., ADJOUSSI P., (2004). La cinématique du trait de côte au Togo vue par télédétection. Geo-Eco-Trop 28, 27-38.

[8] REPUBLIQUE TOGOLAISE, PNUE, (2007). Rapport national sur l'environnement marin et côtier.

[9] FAYE I., (2010). Dynamique du trait de côte sur les littoraux sableux de la Mauritanie à la Guinée-Bissau (Afrique de l'Ouest) : Approches régionale et locale par photo-interprétation, traitement d'images et analyse de cartes anciennes. UB.

[10] LOUATI M., SAIDI H., ZARGOUNI F., (2015). Shoreline change assessment using remote sensing and GIS techniques: a case study of the Medjerda delta coast, Tunisia. Arab. J. Geosci. 8, 4239-4255. Doi: 10.1007/s12517-014-1472-1

[11] BAKAYOKO F., (2016). Cartographie de la dynamique du trait de côte à Grand-Lahou : Utilisation de l'outil «Digital ShorelineAnalysis System (DSAS)». UFHB.

[12] YAVO P., (2016). Cartographie de l'évolution du trait de côte de la zone de Port -Bouet: utilisation de l'outil Digital ShorelineAnalysis System (DSAS) de ArcGis. UFHB d'Abidjan-Cocody. 